\title{
A ketogenic diet reduces amyloid beta 40 and 42 in a mouse model of Alzheimer's disease
}

\author{
Ingrid Van der Auwera ${ }^{1}$, Stefaan Wera ${ }^{1}$, Fred Van Leuven ${ }^{2}$ and \\ Samuel T Henderson*3
}

Address: ${ }^{1} \mathrm{NV}$ reMYND, Minderbroederstraat 12, 3000 Leuven, Belgium, ${ }^{2}$ Experimental Genetics Group, K.U. Leuven - Campus Gasthuisberg O\&N-06.602, B-3000 Leuven, Belgium and ${ }^{3}$ Accera, Inc., 10901 W 120th Ave., Ste 340, Broomfield, CO, 80021, USA

Email: Ingrid Van der Auwera - ingrid.vanderauwera@remynd.be; Stefaan Wera - stefaan.wera@remynd.be; Fred Van Leuven - fredvl@med.kuleuven.ac.be; Samuel T Henderson* - shenderson@accerapharma.com

* Corresponding author

Published: 17 October 2005

Nutrition \& Metabolism 2005, 2:28 doi:10.1 186/1743-7075-2-28
Received: 09 August 2005

Accepted: 17 October 2005

This article is available from: http://www.nutritionandmetabolism.com/content/2/1/28

(C) 2005 Van der Auwera et al; licensee BioMed Central Ltd.

This is an Open Access article distributed under the terms of the Creative Commons Attribution License (http://creativecommons.org/licenses/by/2.0), which permits unrestricted use, distribution, and reproduction in any medium, provided the original work is properly cited.

\begin{abstract}
Background: Alzheimer's disease (AD) is a progressive neurodegenerative disorder that primarily strikes the elderly. Studies in both humans and animal models have linked the consumption of cholesterol and saturated fats with amyloid- $\beta(A \beta)$ deposition and development of $A D$. Yet, these studies did not examine high fat diets in combination with reduced carbohydrate intake. Here we tested the effect of a high saturated fat/low carbohydrate diet on a transgenic mouse model of AD.

Results: Starting at three months of age, two groups of female transgenic mice carrying the "London" APP mutation (APP/V7/7I) were fed either, a standard diet (SD) composed of high carbohydrate/low fat chow, or a ketogenic diet (KD) composed of very low carbohydrate/high saturated fat chow for 43 days. Animals fed the KD exhibited greatly elevated serum ketone body levels, as measured by $\beta$-hydroxybutyrate $(3.85 \pm 2.6 \mathrm{mM})$, compared to SD fed animals $(0.29 \pm$ $0.06 \mathrm{mM}$ ). In addition, animals fed the KD lost body weight (SD $22.2 \pm 0.6 \mathrm{~g}$ vs. KD I7.5 $\pm 1.4 \mathrm{~g}$, $\mathrm{P}$ $=0.0067)$. In contrast to earlier studies, the brief KD feeding regime significantly reduced total brain $A \beta$ levels by approximately $25 \%$. Despite changes in ketone levels, body weight, and $A \beta$ levels, the KD diet did not alter behavioral measures.

Conclusion: Previous studies have suggested that diets rich in cholesterol and saturated fats increased the deposition of $A \beta$ and the risk of developing $A D$. Here we demonstrate that a diet rich in saturated fats and low in carbohydrates can actually reduce levels of $A \beta$. Therefore, dietary strategies aimed at reducing $A \beta$ levels should take into account interactions of dietary components and the metabolic outcomes, in particular, levels of carbohydrates, total calories, and presence of ketone bodies should be considered.
\end{abstract}

\section{Background}

Alzheimer's disease $(\mathrm{AD})$ is an age-associated neurodegenerative disease that is very common in the US, affecting up to $50 \%$ of people between the ages of 75 to 84 years
[1]. The number of cases of AD will increase dramatically in the next 50 years due to the aging population of the developed world and will present an increasing medical challenge [2]. Clinically, $\mathrm{AD}$ is characterized by 
progressive impairment in memory and language and is frequently accompanied by behavioral symptoms, such as anxiety and depression. Pathologically, AD is characterized by accumulation of senile plaques, dystrophic neurites, and neurofibrillar tangles. The plaques contain large amounts of the $\beta$-amyloid $(\mathrm{A} \beta$ ) peptide derived from cleavage of the amyloid precursor protein (APP). Mutations in APP that result in increased generation of a particular form of $A \beta(A \beta 42)$ have been identified in familial cases of $\mathrm{AD}$ and this connection has led to the hypothesis that $A \beta$ is central to the etiology of $A D$ (for review see [3]). However, APP functions as a vesicular transport protein and the etiology of the disease may not be directly related to $A \beta$, but rather to abnormal cleavage of APP and failure to efficiently move vesicles in the axons [4]. While the precise role of $\mathrm{A} \beta$ in $\mathrm{AD}$ remains unresolved, it is clear that $\mathrm{A} \beta$ serves as a pathological marker for the disease.

The development of $\mathrm{AD}$ and the accumulation of $\mathrm{A} \beta$ have been linked to dietary factors. Diets rich in saturated fat have been repeatedly implicated in epidemiological studies [5-8], though they have been difficult to reproduce [9]. In addition, several experiments in mouse models seem to confirm the link between lipid rich diets and AD. Using transgenic mouse models of $\mathrm{AD}$ several groups have reported that high fat diets or diets with added cholesterol increased levels and deposition of the A $\beta$ peptide [10-14]. However, these studies did not examine the effects of lipid rich diets in combination with low carbohydrate intake.

Diets that contain very low carbohydrate and high fat content are well known to induce the hepatic production of ketone bodies ( $\beta$-hydroxybutyrate, acetoacetate and acetone) and are often referred to as ketogenic diets (KD). Ketogenic diets in some aspects mimic starvation and were developed for use in humans to treat epilepsy based on the long record of observations that fasting reduces seizures (for review see [15]). The experimental KD is calorie restricted and has fixed composition and is thus different from low carbohydrate diets used for weight loss, which are usually ad lib and variable in composition. Despite these differences, low carbohydrate diets may also be effective in preventing seizures and may work through similar mechanisms as a KD [16]. The precise mechanism for the anti-convulsant properties of these diets is still unknown. The low carbohydrate content of both diets induce many metabolic changes that may be protective, such as elevated circulating ketone body levels, increased oxidation of fats, changes in protein metabolism, and changes in gene expression $[17,18]$.

\section{Results}

The present study tested experimentally the effects of a KD composed of extremely low carbohydrate and very high saturated fat content in a transgenic mouse model of AD.
The mice express a human APP gene containing the "London" APP mutation (APP/V717I) driven by a thy-1 gene promoter. APP/V717I transgenic mice produce significant levels of soluble $A \beta$ in the brain as early as 3 months of age and exhibit extensive plaque deposition by 12-14 months. The animals demonstrate early behavioral deficits and represent a model of early-onset familial AD [19].

\section{Diet}

Sixteen female APP/V717I mice were fed ad libitum on a standard diet (SD) comprised of a high carbohydrate/ low fat chow (Muracon-G chow: 35\% carbohydrate, 21\% protein, $4.5 \%$ fat, $39.5 \%$ water, fiber, and ash). The predominant fatty acid in Muracon-G is linoleic acid (18:2) and it comprises $1.4 \%$ of the chow by weight. At three months of age half the group ( 8 animals) was switched to a ketogenic diet (KD) comprised of very low carbohydrate/ high fat chow while the remaining 8 animals remained on the SD. In both cases the animals had free access to chow at all times and intake was not experimentally limited. For the KD we used Bio-Serv Inc. F3666 chow: 0.76\% carbohydrates, $8 \%$ protein, $79 \%$ fat, $12 \%$ water, fiber, and ash. F3666 is a ketogenic chow composed of lard, butter fat, dextrose, casein, fiber, corn oil, mineral mix, and a vitamin mix. F3666 is rich in saturated fats. Greater than 29\% of the F3666 chow is composed of saturated fats by weight: $2.4 \%$ myristic acid (C14:0), 18.9\% palmitic acid (C16:0), and 8.4\% stearic (C18:0) (see Table 1). The animals fed the F3666 chow are referred to as the KD group. The mice that remained on the Muracon-G chow are referred to as the SD group.

\section{$K D$ diet and weight loss}

During the first 7 days many of the animals in the KD group were reluctant to eat the new chow and lost weight (Figure 1). To improve consumption and mitigate weight loss, SD chow was mixed with KD chow at a ratio of $1: 3$ starting at day 16 until day 20. For the seven days following day 20 the amount of SD chow was reduced to a few crumbs sprinkled over the KD chow. After day 28 the animals were returned to KD chow only. The mixed chow restored body weights of the KD group to approximately the level of the SD group, at about 20 grams (Figure 1). When the animals were fed KD chow exclusively, body weights again dropped, yet tended to stabilize at approximately 18 grams (Figure 1). At the conclusion of the experiment mean weights were significantly different (SD $22.2 \pm 0.6 \mathrm{~g}$ vs. KD $17.5 \pm 1.4 \mathrm{~g}, \mathrm{p}=0.0067)$.

\section{KD diet elevates serum $\beta$-hydroxybutyrate levels}

To measure the effectiveness of the chow to induce a ketogenic state, blood samples were taken weekly and examined for levels of $\beta$-hydroxybutyrate (BHB). Eight days after switching the chow animals in the KD group had greatly elevated BHB levels compared to the SD group 
Table I: Fatty acid profile of F3666 (KD) chow

\begin{tabular}{|c|c|c|c|}
\hline Fatty acid & $\mathrm{gm} / \mathrm{kg}$ & & $\mathrm{gm} / \mathrm{kg}$ \\
\hline C4 Butanoic & 4.59 & Cl6 Palmitic & 189.03 \\
\hline C6 Hexanoic & 3.19 & CI6:I cis-9-Hexadecenoic & 28.18 \\
\hline C8 Octanoic & 2.99 & CI7 Heptadecanoic & 2.38 \\
\hline CIO Decanoic & 4.39 & CI7:I Heptadecenoic & 1.43 \\
\hline CI0:I Decenoic & 0.80 & Cl8 Stearic & 84.79 \\
\hline $\mathrm{Cl} 2$ Lauric & 6.41 & CI8.I Oleic & 298.34 \\
\hline CI2:I cis-9-Dodecenoic & 0.40 & CI8:2 Linoleic & 119.44 \\
\hline Cl4 Myristic & 24.43 & CI8:3 Linolenic & 6.33 \\
\hline CI4:I cis-9-Tetradecenoic & 6.14 & C20 Eicosanoic & 1.18 \\
\hline CI5 Pentadecanoic & 0.48 & C20:I cis-II-Eicosenoic & 3.80 \\
\hline
\end{tabular}

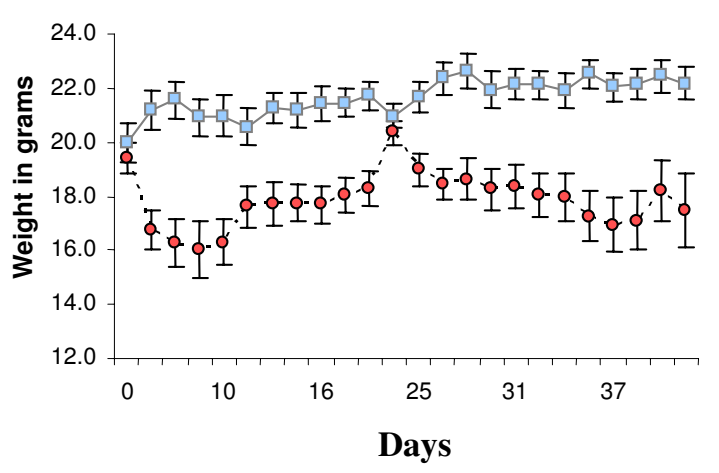

Figure I

Average weight in grams of each group during the course of the experiment. Blue squares represent standard diet (SD) group. Red circles represent ketogenic diet (KD) group. Error bars represent standard error of the mean. Days signify time in days from start of diet change. Animals on KD lost weight. To mitigate weight loss and improve feeding a small amount of SD chow was mixed with KD chow during the second week and then removed on the third week, see methods.
$(\mathrm{SD} 0.26 \pm 0.023 \mathrm{mM}$ vs. $\mathrm{KD} 8.94+1.8 \mathrm{mM}, \mathrm{p}<0.0001$ Figure 2), possibly due to some animals not eating. As expected, feeding the mixed chow on days 16-28 reduced serum ketone bodies (Figure 2). Yet, at all time points examined after day 0 ketone levels were significantly greater in the KD fed group compared to the SD group (Figure 2). The average serum $\mathrm{BHB}$ concentration over the course of the experiment was elevated in the KD group compared to the SD group (SD $0.29 \pm 0.06 \mathrm{mM}$ vs. KD $3.85 \pm 1.1 \mathrm{mM}, \mathrm{p}<0.0078)$. The elevated ketone levels in

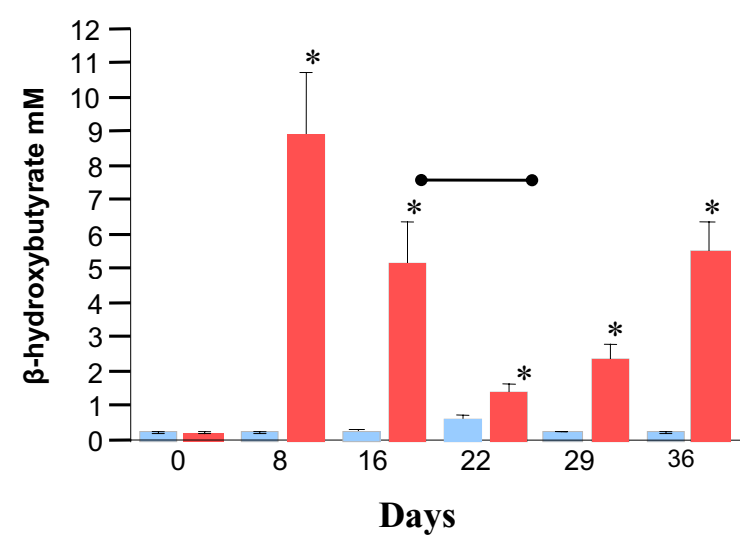

Figure 2

Ketogenic diet induces ketone bodies production. Standard diet (SD) group shown in blue, ketogenic diet (KD) group shown in red, error bars represent standard error of the mean. Serum $\beta$-hydroxybutyrate (BHB) levels in $\mathrm{mM}$. * indicates $p<0.05$ between KD and SD group. Days signify time in days from start of diet change. Serum $\beta$-hydroxybutyrate levels were significantly elevated in KD group at all time points after day 0 . Bar indicates period of mixed chow for KD group.

the KD group suggested that a metabolic shift toward fat utilization had occurred in these animals.

\section{Cognitive testing}

After 38 days on the diet animals were tested for behavioral deficits using object recognition tests as previously described [20], see methods. Despite the differences in chow, BHB levels, and weight loss, no difference in behavioral measures were detected between the groups (Table 2). 


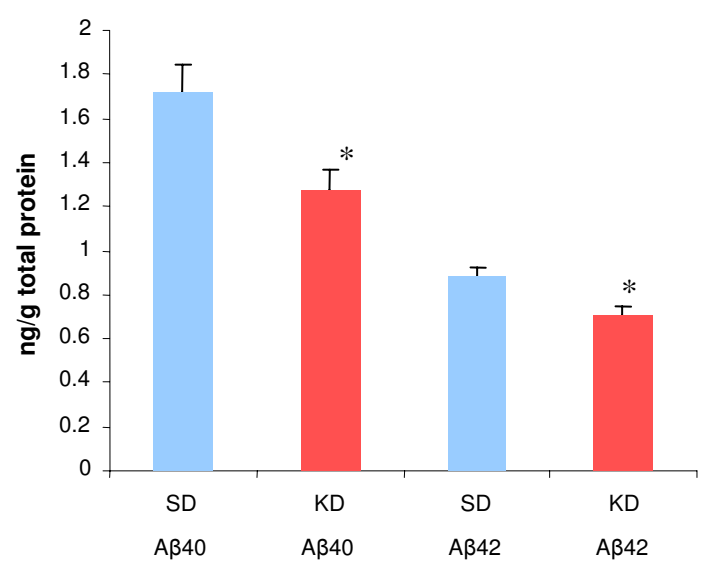

\section{Figure 3}

Ketogenic diet reduces $A \beta 40$ and $A \beta 42$. $A \beta$ levels as $n g / g$ of brain tissue. Standard diet (SD) group shown in blue, ketogenic diet (KD) group shown in red, error bars represent standard error of the mean. SD chow A $3401.72 \pm 0.12$ $\mathrm{ng} / \mathrm{g}$ vs. $\mathrm{KD}$ chow $\mathrm{A} \beta 40 \mathrm{I} .28 \pm 0.09 \mathrm{ng} / \mathrm{g}, \mathrm{p}=0.012$. SD chow $\mathrm{A} \beta 420.88 \pm 0.05 \mathrm{ng} / \mathrm{g}$ vs. KD chow $\mathrm{A} \beta 420.7 \mathrm{I} \pm 0.0 .4 \mathrm{ng} / \mathrm{g}, \mathrm{P}$ $=0.016$.

Table 2: Recognition Index

\begin{tabular}{lccc}
\hline Test & SD & KD & P value \\
\hline RI by time & $56.2 \pm 5.7$ & $56.7 \pm 8.2$ & 0.963 \\
Curiosity by time & $10.0 \pm 2.7$ & $11.6 \pm 6.5$ & 0.803 \\
RI by frequency & $49.3 \pm 3.6$ & $54.6 \pm 9.7$ & 0.628 \\
Curiosity by frequency & $14.4 \pm 2.3$ & $11.9 \pm 3.9$ & 0.530 \\
Mean velocity & $3.8 \pm 0.4$ & $4.5 \pm 0.8$ & 0.447 \\
\hline
\end{tabular}

\section{A $\beta$ levels}

At four months of age APP/V717I mice do not possess A $\beta$ positive plaques and all the $A \beta$ is present in the soluble fraction [19]. Therefore, 43 days after dietary change levels of soluble $A \beta$ in the brain were measured in both groups of animals. Brain homogenate was isolated as previously described [20], see methods. One hemisphere from each animal was analyzed for both $A \beta 40$ and 42 levels using the Amyloid $A \beta 40$ or $A \beta 42$ ELISA High Sensitivity Kit (The Genetics Company, Zurich, Switzerland). Levels of both soluble $A \beta 40$ and 42 were found to be significantly lower in the KD fed group (Figure 3 ). In cases of familial AD excess $A \beta 42$ is produced relative to $A \beta 40$ thereby increasing the $A \beta 42 / 40$ ratio. We examined the ratio of $A \beta 42$ to $\mathrm{A} \beta 40$ and found no difference between groups (SD $0.51 \pm$
0.024 vs. KD $0.56 \pm 0.026, p=0.2872)$, suggesting that the diet did not alter cleavage sites on APP, but instead promoted a general lowering of $A \beta$ species.

Total protein levels were examined to determine if a general decline in brain protein in the KD group could explain the decrease in $\mathrm{A} \beta$ levels. However, protein levels, measured as $\mathrm{mg} / \mathrm{ml}$ of brain homogenate, did not differ between the two groups (SD $0.56 \pm 0.035 \mathrm{mg} / \mathrm{ml}$ vs. KD $0.51 \pm 0.017 \mathrm{mg} / \mathrm{ml}, \mathrm{p}=0.213$ ). Since most (though not all) of the animals in the KD group lost weight, the animals with the greatest weight loss may have been expected to have the lowest $A \beta$ levels. However, the levels of $A \beta 40$ or $A \beta 42$ did not correlate with weight change across all groups $(\mathrm{A} \beta 40 \mathrm{r}=0.16, \mathrm{p}=0.20 ; \mathrm{A} \beta 42 \mathrm{r}=0.05, \mathrm{p}=0.49)$ or in the KD group alone $(\mathrm{A} \beta 40 \mathrm{r}<0.0001, \mathrm{p}=0.96$; $\mathrm{A} \beta 42$ $r=0.09, p=0.62)$. Both of these measures suggest that the $A \beta$ lowering effect is not the result of a general lowering of protein levels due to weight loss.

A better measure of the effectiveness of the ketogenic diet was serum BHB levels, since all the animals in the KD group exhibited elevated BHB levels. When A $\beta 40$ and 42 levels from all animals were correlated with the average serum $\mathrm{BHB}$ over the course of the experiment, a significant correlation was observed $(\mathrm{A} \beta 40 \mathrm{r}=0.42, \mathrm{p}=0.016$; $\mathrm{A} \beta 42 \mathrm{r}=0.42, \mathrm{p}=0.016$ ). However, this correlation was most likely driven by the large differences in BHB and $A \beta$ levels between the two groups, since there was no significant correlation between $A \beta$ and BHB levels in the KD group alone $(\mathrm{A} \beta 40 \mathrm{r}=0.083, \mathrm{p}=0.58 ; \mathrm{A} \beta 42 \mathrm{r}=0.15, \mathrm{p}=$ $0.46)$.

\section{Discussion}

This study demonstrated the unexpected result that a brief treatment with a low carbohydrate/high saturated fat diet reduced total $A \beta$ levels in a mouse model of Alzheimer's disease. Previous studies had suggested that diets rich in saturated fats or cholesterol increased both the production and deposition of $\mathrm{A} \beta$ in mouse models of $\mathrm{AD}$, leading to the suggestion that diets rich in lipids were a factor in $\mathrm{AD}[10,12-14]$. However, these diets were not low carbohydrate diets. In the high cholesterol diets, cholesterol was added to the diet without reduction in other components $[10,14]$. In the studies of high fat diets, carbohydrate content was still relatively high. For example, Ho et al. used a diet of $60 \%$ fat, $20 \%$ carbohydrate, $20 \%$ protein. This diet was sufficiently high in carbohydrate to cause large increases in body weight in the animals [11].

The interaction of different macronutrients, in particular fats and carbohydrates, is known to influence the metabolic state of the animal. For example, Marsset-Baglieri et al. examined if fat in the diet alone was sufficient to shift energy balance toward fat storage. Yet, rats fed ad libitum 
high fat (50\%) diets devoid of carbohydrates did not increase energy intake and did not gain in body adiposity, while animals fed high fat diets $(30 \%)$ in the presence of carbohydrates $(56 \%)$ increased energy intake and gained in body fat [21]. Such studies support the view that when fat and carbohydrates are consumed simultaneously, the carbohydrates stimulate insulin secretion and thereby promote storage of fat (for recent review see [22]). Therefore, it is important to consider the macronutrient profile of the diet when examining the effects of dietary fat on biological processes.

In the present study, transgenic animals were fed ad libitum a very high fat $(79 \%)$ diet that was practically devoid of carbohydrates $(0.76 \%)$. The KD resulted in ketone body production, weight loss, and decreased $A \beta$ levels. Hence, the data presented here suggests that it may not be fats in the diet that increases $A \beta$ levels, but perhaps levels of total calories, carbohydrates, or the metabolic state of the animal.

Epidemiological studies in humans have implicated saturated fats in the diet as a risk factor for Alzheimer's disease. For example, Kalmijn et al. correlated eating habits with incidence of dementia after a two year follow-up in a large study of 5,386 subjects in Rotterdam, NL. The results from this analysis led the author to suggest that diets rich in saturated fats and cholesterol increased the risk of several types of dementia [5]. However, after a 6 year follow-up of this same population, no correlation between dementia and fat intake could be identified, leading the authors to conclude "High intake of total, saturated, and trans fat and cholesterol and low intake of MUFA, PUFA, n-6 PUFA, and n-3 PUFA were not associated with increased risk of dementia or its subtypes." [9]. More recent studies have also examined the link between dietary fat and cognitive decline. In a study of 2,560 participants ages 65 and older in the Chicago Health and Aging project, fat intake was measured by food questionnaire and correlated with cognitive testing examined after a 3 and 6 year follow- up. This large study found only weak trends between saturated fat and cholesterol intake and cognitive decline [7]. Both the rodent and human studies highlight the complications of trying to link complex environmental factors, such as eating habits or macronutrient intake, with dementia and Alzheimer's disease. In particular, one complicating factor in the human studies is the normal consumption of large amounts of carbohydrates in modern diets.

The present study demonstrates that, contrary to expectations, transgenic mice fed ab libitum a very low carbohydrate/high saturated fat diet present lower levels of $A \beta$ after only 43 days of dietary change. The KD group exhibited low levels of both $A \beta 40$ and the more amyloidic
$A \beta 42$, suggesting that the $\mathrm{KD}$ diet did not change or increase the efficiency of cleavage sites within APP. Instead the data suggests the KD regime either reduced processing of APP or increased degradation of A $\beta$ species. Most of the animals administered the ketogenic diet lost body weight as well as exhibited reduced $A \beta$ levels. However, the reduced $A \beta$ levels may not have been due to a general lowering of protein content. Total brain protein levels did not differ between the groups and $A \beta$ levels did not correlate with weight loss. Interestingly, despite change in diet, weight loss, and $A \beta$ levels, no change in cognitive performance was observed (Table 2). This observation agrees with the general finding that $\mathrm{KD}$ diets are not harmful to mice [23]. Also, the finding that reduction in $\mathrm{A} \beta$ did not improve cognitive performance may be due to the modest lowering of levels under these conditions and longer treatment may be required.

The KD diet was developed to mimic a starvation response in animals without reducing calories to harmful levels [15]. In this way a KD is similar to caloric restriction (CR) regimes that have been used in many species to alter aging and increase some forms of stress resistance. CR typically reduces calories $30-40 \%$ compared to ad libitum fed animals and has numerous positive effects on animal health [24]. In the present study we did not attempt to restrict calories in any way and the animals had free access to the ketogenic chow at all times and intake was self limited. However, since the animals were reluctant at first to eat the KD chow and we observed weight loss in the KD group, we cannot rule out the possibility that the $A \beta$ lowering effects were due to $\mathrm{CR}$.

Yet, CR and KD may work through similar mechanisms. $\mathrm{KD}$ are well known to reduce insulin signaling and mimic starvation, thereby increasing fatty acid oxidation and promoting a catabolic state [17]. Similarly, CR is well known to reduce serum insulin and IGF levels and much of the benefit of CR may derive from this reduction in insulin/IGF signaling (for review see [25]). For example, decreased insulin/IGF-like signaling inhibits protein synthesis and promotes protein degradation, which may lead to the clearing of degradation-sensitive proteins, such as amyloidic peptides.

Increasing evidence suggests a role for insulin/IGF-1 in regulating APP and modulating $A \beta$ levels. Receptors for both insulin and IGF-1 are highly expressed in brain, especially in hippocampus and cortex, where they may influence learning and memory [26]. Insulin signaling in the brain increases extracellular levels of $A \beta$ by promoting secretion [27] and inhibiting degradation by insulindegrading enzyme [28]. This view has also gained recent support in humans. Fishel et al. demonstrated that induced hyperinsulinemia in healthy elderly subjects 
elevated both serum and spinal fluid $A \beta$ levels, suggesting insulin plays a role in elevating $A \beta$, especially under conditions such as type II diabetes [29].

Such an interpretation is consistent with recent studies demonstrating similar $A \beta$ lowering effects of a low carbohydrate, caloric restriction (CR) regime in mice expressing the "Swedish" form of APP (Tg2576 mice). In these animals, lower levels of $A \beta 40$ and 42 were detected in animals fed 30\% less carbohydrates than ad libitum fed animals. The $\mathrm{A} \beta$ lowering effect may have been due to increased $\alpha$-secretase and insulin degrading enzyme activity in the CR animals [30].

Alternatively, other physiologic changes may have reduced $A \beta$ levels in this study. The high levels of ketone bodies alone may have contributed to increased protein turnover. Ketone bodies added to cell culture have been shown to lead to increased oxidation of proteins prone to oxidative damage. The presence of damaged protein triggers proteolysis of normally long lived proteins via chaperone-mediated autophagy [31]. Such a mechanism may be at work in animals fed a ketogenic chow and exposed to high levels of ketone bodies. Some support for this model comes from the observation that elevated ketone body levels correlated better with lowering of $A \beta$ species than did weight loss. In addition, ketone bodies may serve as an efficient substrate for neuronal metabolism. Previous studies have shown that acute elevation of ketone bodies may improve cognitive performance in some individuals with mild to moderate $\mathrm{AD}$ [32].

\section{Conclusion}

As the population of the developed world ages the incidence of $\mathrm{AD}$ is predicted to increase dramatically and will place a tremendous burden on health services [2]. Dietary intervention represents a relatively safe and readily available method to combat $\mathrm{AD}$. Yet, the key dietary links remain unclear. Much of the earlier work has focused on the role of high fat or high cholesterol diets and their contribution to $\mathrm{AD}$. However, evidence suggests that the primary genetic risk factor for late onset $\mathrm{AD}$, the epsilon4 allele of apolipoprotein E, may have been selected against in populations with long historical exposure to agriculture [33]. In addition, foods rich in carbohydrates are relatively recent additions to the human diet and are likely to be more evolutionarily discordant than high fat diets [34]. Therefore, the recent evolutionary switch to high carbohydrate (HC) diets may play an important role in development of $\mathrm{AD}$. HC diets are well known to stimulate insulin signaling and result in a suppression of lipid metabolism [22]. Thus, such diets may lead to inappropriate lipid environments in neurons, mis-cleavage of APP and the resulting inhibition of cellular trafficking, and ultimately increasing the risk of developing $\mathrm{AD}$ (for overview see [35]).

\section{Methods \\ Animals}

Sixteen APP [V717I] C57Bl $\times$ FVB female mice of 3 months of age were used for this study. Mice were housed under a reversed day-night rhythm: 14 hours light/10 hours darkness starting at 7 p.m. in standard metal cages type RVS T2 (area of $540 \mathrm{~cm} 2$ ). The number of mice per cage was limited in accordance with legislation on animal welfare. All mice were genotyped by polymerase chain reaction (PCR) at the age of 3 weeks. Mice were blind randomized and age-matched and had free access to pre-filtered and sterile water (UV-lamp). Mice had free access to either ketogenic (KD) (code F3666, Bio-Serv, Frenchtown, US) or standard (SD) chow (Muracon-G, Trouw Nutrition, Gent). The F3666 chow is a runny paste and was given in special designed liquid food suppliers and was refreshed daily. F3666 is a liquid chow and the animals frequently spilled the chow in the cage. Also, since all the animals in a given group were housed together in a single cage, measuring chow intake per animal was not possible and was not recorded. Due to some problems with weight loss in animals in the KD group, these animals were fed a mixed chow 1(SD):3(KD) starting at day 16 until day 20 . From days 21-27 the amount of SD chow was reduced to a few crumbs sprinkled over the KD chow. After day 28 the animals were returned to KD chow only. However, one mouse in the KD group refused food intake and died despite attempts of feeding via gavage. One control animal died during blood draw.

\section{Blood collection and analysis}

Blood was collected from anesthetized mice from either the orbital plexus or via a heart puncture. $\beta$-hydroxybutyrate levels were measured spectrophotometrically using the Stanbio liquicolor $\beta$-hydroxybutyrate kit (Stanbio Inc., Boerne, Texas).

\section{Novel object recognition test}

The novel object recognition test was performed after 38 days of treatment using the method described by Dewachter et al. [20]. Briefly, mice were familiarized for one hour to a Plexiglas open-field box $(52 \times 52 \times 40 \mathrm{~cm})$ with black vertical walls and a translucent floor, dimly illuminated by a lamp placed underneath the box. The next day the animals were placed in the same box and submitted to a 10 minute acquisition trial. During this trial mice were placed individually in the open field in the presence of $2 \times$ object A (orange barrel or green cube, similar sized of $\pm 4 \mathrm{~cm}$ ), and the duration (time AA) and the frequency (Freq AA) exploring object A (when the animals snout was directed towards the object at a distance of $<1$ $\mathrm{cm}$ and the mice were actively sniffing in the direction of 
the object) was recorded by a computerized system (Ethovision, Noldus information Technology, Wageningen, the Netherlands). During the 10 minute retention trial (second trial) performed 3 hours later, a novel object (object $\mathrm{B}$, green cube or orange barrel) was placed together with the familiar object (object A) into the open field. (Freq A and Freq B and Time A and Time B, respectively). The recognition index (RI), defined as the ratio of the duration in which the novel object was explored over the duration in which both objects were explored (Time $\mathrm{B} /$ (Time A + Time B) $\times 100$ ), was used to measure non-spatial memory. The duration and frequency object $A$ was explored during the acquisition trial (Time AA and Freq AA) was used to measure curiosity.

\section{Analytical techniques}

The mice were anaesthetized with a mixture of Ketalar ${ }^{\circledast}$ (Ketamin), Rompun ${ }^{\circledast}$ (Xylazin 2\%) and Atropine (2:1:1) and flushed trans-cardially with physiological serum at $4^{\circ} \mathrm{C}$. This was performed to remove blood from the brain vessels, a procedure which has no influence on organ integrity. Blood was collected via a heart puncture and a 1 $\mathrm{ml}$ syringe in heparinized Eppendorf tubes. The brain was removed from the cranium and hindbrain and forebrain were separated with a cut in the coronal/frontal plane. The forebrain was divided evenly into left and right hemisphere by using a midline sagittal cut. One hemisphere of each animal was homogenized using a Potter, a glass tube (detergent free, $2 \mathrm{~cm}^{3}$ ) and a mechanical homogenizer (650 rpm). A volume of $6.5 \times 1 / 2$ brain weight of freshly prepared $20 \mathrm{mM}$ Tris/HCl buffer (pH 8.5) with Proteinase Inhibitors (1 tablet per $50 \mathrm{ml}$ Tris/HCl buffer, CompleteTM, Roche, Mannheim, Germany) was used as homogenization buffer. The homogenates were collected in Beckman centrifuge tubes TLX and collected on ice prior to centrifugation. Before the samples were centrifuged, $10 \%$ of the sample was used for determination of the total protein concentration of the homogenate whereas $90 \%$ of the samples were centrifuged to process further for biochemistry. The supernatant (soluble fraction containing secreted APP and amyloid peptides) was separated from the pellet by centrifugation (membrane fraction containing membrane-bound APP-fragments). The supernatant was processed further by column chromatography to concentrate the amyloid peptides using small reversed phase columns (C18-Sep-Pack Vac 3cc cartridges, Waters, Massachusetts, MA). Amyloid peptides were eluted with 75\% A-TFA and the eluates were collected in $2 \mathrm{ml}$ tubes on ice. Eluates were freeze-dried in a speedvac concentrator (Savant, Farmingdale, NY) overnight and resolved in $240 \mu \mathrm{l}$ of the sample diluent furnished with the ELISA kits. To quantify the amount of human $A \beta 40$ and human $A \beta 42$ in the soluble fraction of the brain homogenates, commercially available EnzymeLinked-Immunosorbent-Assay (ELISA) kits were used (h
Amyloid A $\beta 40$ or $A \beta 42$ ELISA high sensitive, The Genetics Company, Zurich, Switzerland). Quantification of the $A \beta$ content of the samples was obtained by comparing absorbance to a standard curve made with synthetic $A \beta 40$ or $A \beta 42$. Total protein concentration in the brain homogenate was measured using Bradford solution (Pierce Inc.).

\section{List of abbreviations}

$\mathrm{AD}$, Alzheimer's disease; APP, amyloid precursor protein; $\mathrm{A} \beta$, amyloid beta; $\mathrm{SD}$, standard diet; $\mathrm{KD}$, ketogenic diet; $\mathrm{CR}$, caloric restriction; $\mathrm{BHB}, \beta$-hydroxybutyrate.

\section{Competing interests}

As co-founder of Accera, Inc., STH holds shares in an organization and may gain or lose financially from the publication of this manuscript. In addition, STH has applied for patents relating to the content of the manuscript and may gain or lose financially from publication of this manuscript.

\section{Acknowledgements}

We thank the staff of Accera, Inc. for critical reading of this manuscript and helpful discussions.

\section{References}

I. Evans DA, Funkenstein HH, Albert MS, Scherr PA, Cook NR, Chown MJ, Hebert LE, Hennekens CH, Taylor JO: Prevalence of Alzheimer's disease in a community population of older persons. Higher than previously reported. Jama 1989, 262:255 I-2556.

2. Hebert LE, Scherr PA, Bienias JL, Bennett DA, Evans DA: Alzheimer disease in the US population: prevalence estimates using the 2000 census. Arch Neurol 2003, 60: I I 19-I I 22.

3. Selkoe DJ: Alzheimer's disease: genes, proteins, and therapy. Physiol Rev 200I, 8I:74I-766.

4. Stokin GB, Lillo C, Falzone TL, Brusch RG, Rockenstein E, Mount SL, Raman R, Davies P, Masliah E, Williams DS, Goldstein LS: Axonopathy and transport deficits early in the pathogenesis of Alzheimer's disease. Science 2005, 307:1282-1288.

5. Kalmijn S, Launer LJ, Ott A, Witteman JC, Hofman A, Breteler MM: Dietary fat intake and the risk of incident dementia in the Rotterdam Study. Ann Neurol 1997, 42:776-782.

6. Grant WB: Dietary links to Alzheimer's disease: 1999 update. J Alzheimers Dis 1999, I:197-201.

7. Morris MC, Evans DA, Bienias JL, Tangney CC, Wilson RS: Dietary fat intake and 6-year cognitive change in an older biracial community population. Neurology 2004, 62:I573-I579.

8. Morris MC, Evans DA, Bienias JL, Tangney CC, Bennett DA, Aggarwal $\mathrm{N}$, Schneider J, Wilson RS: Dietary fats and the risk of incident Alzheimer disease. Arch Neurol 2003, 60:194-200.

9. Engelhart MJ, Geerlings MI, Ruitenberg A, Van Swieten JC, Hofman A Witteman JC, Breteler MM: Diet and risk of dementia: Does fat matter?: The Rotterdam Study. Neurology 2002, 59:1915-1921.

10. Refolo LM, Malester B, LaFrancois J, Bryant-Thomas T, Wang R, Tint GS, Sambamurti K, Duff K, Pappolla MA: Hypercholesterolemia accelerates the Alzheimer's amyloid pathology in a transgenic mouse model. Neurobiol Dis 2000, 7:321-331.

II. Ho L, Qin W, Pompl PN, Xiang Z, Wang J, Zhao Z, Peng Y, Cambareri G, Rocher A, Mobbs CV, Hof PR, Pasinetti GM: Diet-induced insulin resistance promotes amyloidosis in a transgenic mouse model of Alzheimer's disease. Faseb J 2004, I 8:902-904.

12. Levin-Allerhand JA, Lominska CE, Smith JD: Increased amyloidlevels in APPSWE transgenic mice treated chronically with a physiological high-fat high-cholesterol diet. J Nutr Health Aging 2002, 6:315-319. 
13. Shie FS, Jin LW, Cook DG, Leverenz JB, LeBoeuf RC: Diet-induced hypercholesterolemia enhances brain $A$ beta accumulation in transgenic mice. Neuroreport 2002, 13:455-459.

14. George AJ, Holsinger RM, McLean CA, Laughton KM, Beyreuther K, Evin G, Masters CL, Li QX: APP intracellular domain is increased and soluble Abeta is reduced with diet-induced hypercholesterolemia in a transgenic mouse model of Alzheimer disease. Neurobiol Dis 2004, 16:124-132.

15. Thio LL, Sitzwohl A, Trevathan E: The ketogenic diet. In American Academy of Pediatrics Pediatric Nutrition Handbook 5th edition. Edited by: Kleinman RE. Elk Grove Village IL, American Academy of Pediatrics; 2002.

16. Kossoff EH, Krauss GL, McGrogan JR, Freeman JM: Efficacy of the Atkins diet as therapy for intractable epilepsy. Neurology 2003, 61:1789-179|.

17. Stafstrom CE: Dietary approaches to epilepsy treatment: old and new options on the menu. Epilepsy Curr 2004, 4:2 I 5-222.

18. Sullivan PG, Rippy NA, Dorenbos K, Concepcion RC, Agarwal AK, Rho JM: The ketogenic diet increases mitochondrial uncoupling protein levels and activity. Ann Neurol 2004, 55:576-580.

19. Moechars D, Dewachter I, Lorent K, Reverse D, Baekelandt V, Naidu A, Tesseur I, Spittaels K, Haute CV, Checler F, Godaux E, Cordell B, Van Leuven F: Early phenotypic changes in transgenic mice that overexpress different mutants of amyloid precursor protein in brain. J Biol Chem 1999, 274:6483-6492.

20. Dewachter I, Reverse D, Caluwaerts N, Ris L, Kuiperi C, Van den Haute C, Spittaels K, Umans L, Serneels L, Thiry E, Moechars D, Mercken M, Godaux E, Van Leuven F: Neuronal deficiency of presenilin I inhibits amyloid plaque formation and corrects hippocampal long-term potentiation but not a cognitive defect of amyloid precursor protein [V7/7I] transgenic mice. J Neurosci 2002, 22:3445-3453.

21. Marsset-Baglieri A, Fromentin G, Tome D, Bensaid A, Makkarios L, Even PC: Increasing the protein content in a carbohydratefree diet enhances fat loss during $35 \%$ but not $\mathbf{7 5} \%$ energy restriction in rats. J Nutr 2004, 134:2646-2652.

22. Hellerstein MK: Carbohydrate-induced hypertriglyceridemia: modifying factors and implications for cardiovascular risk. Curr Opin Lipidol 2002, 13:33-40.

23. Rho JM, Sarnat HB, Sullivan PG, Robbins CA, Kim DW: Lack of longterm histopathologic changes in brain and skeletal muscle of mice treated with a ketogenic diet. I Child Neurol 2004, 19:555-557.

24. Masoro E): Caloric restriction. Aging (Milano) 1998, 10:173-174.

25. Bordone L, Guarente L: Calorie restriction, SIRTI and metabolism: understanding longevity. Nat Rev Mol Cell Biol 2005, 6:298-305.

26. Wickelgren I: Tracking insulin to the mind. Science 1998 280:517-519.

27. Gasparini L, Gouras GK, Wang R, Gross RS, Beal MF, Greengard P, $\mathrm{Xu} \mathrm{H}$ : Stimulation of beta-amyloid precursor protein trafficking by insulin reduces intraneuronal beta-amyloid and requires mitogen-activated protein kinase signaling. J Neurosci 200I, 2 I:256I-2570.

28. Vekrellis K, Ye Z, Qiu WQ, Walsh D, Hartley D, Chesneau V, Rosner $M R$, Selkoe DJ: Neurons regulate extracellular levels of amyloid beta-protein via proteolysis by insulin-degrading enzyme. J Neurosci 2000, 20:1657-1665.

29. Fishel MA, Watson GS, Montine TJ, Wang Q, Green PS, Kulstad J Cook DG, Peskind ER, Baker LD, Goldgaber D, Nie W, Asthana S, Plymate SR, Schwartz MW, Craft S: Hyperinsulinemia Provokes Synchronous Increases in Central Inflammation and \{beta\}Amyloid in Normal Adults. Arch Neurol 2005, 62 (I 0): I 539-44.

30. Wang J, Ho L, Qin W, Rocher AB, Seror I, Humala N, Maniar K, Dolios G, Wang R, Hof PR, Pasinetti GM: Caloric restriction attenuates beta-amyloid neuropathology in a mouse model of Alzheimer's disease. Faseb / 2005, 19:659-66 I.

31. Finn PF, Dice JF: Ketone bodies stimulate chaperone-mediated autophagy. J Biol Chem 2005, 280(27):25864-70.

32. Reger MA, Henderson ST, Hale C, Cholerton B, Baker LD, Watson GS, Hyde K, Chapman D, Craft S: Effects of beta-hydroxybutyrate on cognition in memory-impaired adults. Neurobiol Aging 2004, 25:3||-3|4.

33. Corbo RM, Scacchi R: Apolipoprotein E (APOE) allele distribution in the world. Is APOE*4 a 'thrifty' allele? Ann Hum Genet 1999, 63 ( Pt 4):30I-310.
34. Cordain L, Eades MR, Eades MD: Hyperinsulinemic diseases of civilization: more than just Syndrome X. Comp Biochem Physiol A Mol Integr Physiol 2003, 136:95-I I 2.

35. Henderson ST: High carbohydrate diets and Alzheimer's disease. Med Hypotheses 2004, 62:689-700.
Publish with Bio Med Central and every scientist can read your work free of charge

"BioMed Central will be the most significant development for disseminating the results of biomedical research in our lifetime. "

Sir Paul Nurse, Cancer Research UK

Your research papers will be:

- available free of charge to the entire biomedical community

- peer reviewed and published immediately upon acceptance

- cited in PubMed and archived on PubMed Central

- yours - you keep the copyright

Submit your manuscript here:

http://www.biomedcentral.com/info/publishing_adv.asp
BioMedcentral 